\title{
Local stress fields and intraplate deformation of Iberia: variations in spatial and temporal interplay of regional stress sources
}

\author{
B. Andeweg a,*, G. De Vicente ${ }^{\mathrm{b}}$, S. Cloetingh ${ }^{\mathrm{a}}$, J. Giner ${ }^{\mathrm{b}}$, A. Muñoz Martin ${ }^{\mathrm{b}}$ \\ ${ }^{a}$ Vrije Universiteit Amsterdam, De Boelelaan 1085, 1081 HV Amsterdam, Netherlands \\ ${ }^{b}$ Universidad Complutense, Madrid, Spain
}

Received 16 March 1998; accepted 14 June 1998

\begin{abstract}
Tertiary to present deformation in the interior of the Iberian Peninsula reflects spatial and temporal variations of the activity of the plate boundaries. Local deformation patterns observed in many of the numerous intraplate Tertiary basins and their borders, such as the Madrid Basin and the Sierra de Altomira, are at first sight incompatible with the regional stress field under which they were formed. We demonstrate, however, that they can be explained as the effect of several stress fields that acted on the Iberian Peninsula from earliest Tertiary onward. Data on local deformation can constrain both magnitudes and directions of forces acting on the plate boundaries of Iberia, enabling us to estimate the relative importance of the different plate driving and deforming mechanisms providing further constraints on the tectonic evolution of Iberia. (c) 1999 Elsevier Science B.V. All rights reserved.
\end{abstract}

Keywords: stress evolution; intraplate deformation; Tertiary; tectonics; Iberia

\section{Introduction}

During its evolution from the early Cenozoic to present, the microplate Iberia has been affected by a series of far-field stress sources, varying in both orientation and nature (e.g. Galindo-Zaldivar et al., 1993; Muñoz Martin et al., 1998). During the active tectonic history, the fractured Hercynian basement in the interior of Iberia was repeatedly reactivated under these different stress fields. A large number of Cenozoic basins (see Fig. 1) were formed and subsequently deformed by reactivation of basement faults under the changing stress field. The effects of the

\footnotetext{
* Corresponding author. Tel.: +31 20 4447353; Fax:

+3120 6462457; E-mail: andb@geo.vu.nl
}

far-field stresses, caused by activity of lithospheric plates (e.g. Argus et al., 1989), can in this way be observed throughout large parts of the continent, up to $1000 \mathrm{~km}$ from its active boundaries. Structural data found in these plate interior basins provide indirect data on the activity of the plate boundaries. The Iberian Peninsula is due to its plate tectonic setting, abundant moderate internal deformation and well studied sedimentary record (e.g. Calvo et al., 1993), a natural laboratory to study the dynamics of intraplate deformation as the result of plate tectonic activity.

In this paper we will discuss constraints on the geodynamics of the Iberian microplate from Tertiary onwards provided by plate tectonic reconstruction and palaeostress indicator data. Subsequently we 


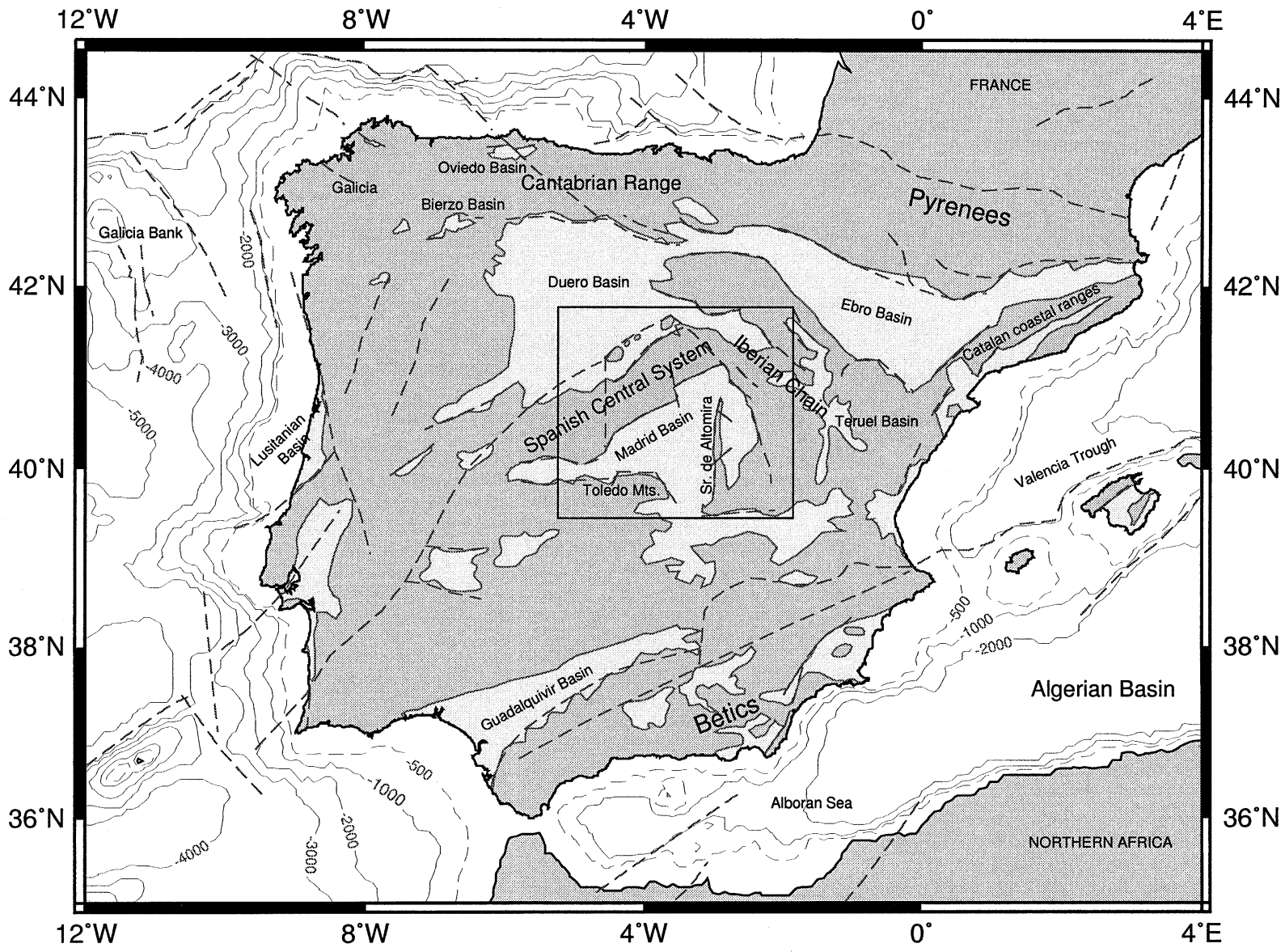

Fig. 1. Location map of Iberia showing undifferentiated basement (dark grey) and the major late Cenozoic basins (lighter grey). Dashed lines indicate the most important Tertiary to present faults. For the oceanic part bathymetry is added to show steep topography gradient of the northern and western coasts of Iberia. Box marks the location of Fig. 4.

present three examples of local deformation in the interior of the Iberian continent and their relationship with local stress fields induced by spatial and temporal interplay of regional stress sources.

\subsection{Tectonic setting of the Iberian Peninsula}

The driving force behind the changing far-field stresses affecting Iberia was the differential movement between Eurasia, Africa and Iberia due to the progressive opening of the Atlantic. Spreading of the Azores part of the North Atlantic $(\sim 126 \mathrm{Ma})$ and the Biscay $(\sim 115 \mathrm{Ma})$ caused Iberia to rotate anti-clockwise with respect to Eurasia (Savostin et al., 1986) causing left lateral motion between Iberia and Eurasia, coincident with collision, and subduction of the Ligurian Basin to the east of Iberia (De Jong, 1990). At about 85 Ma the Biscay opening failed and the Atlantic continued opening in a northern direction (Ziegler, 1988; Srivastava et al., 1990), causing convergence between Iberia and Eurasia. This resulted in deformation starting in the Campanian (Puigdefabregas and Souquet, 1986) along the northern fringe of the Iberian Plate creating the Pyrenees and causing inversion of Mesozoic extensional basins (Garcia-Mondejar, 1996) to a short-lived subduction in the Biscay region during latest Cretaceous to Early Eocene (Boillot and Malod, 1988). The termination of this subduction is coinciding with the separation of the rotation poles of Africa and Iberia 
as proposed by Savostin et al. (1986) at around $54 \mathrm{Ma}$ and the onset of oceanic spreading on the western side of Greenland. This is the start of limited differential motion between Africa and Iberia, which seems to be reflected in the pattern of ocean floor age distribution. Final amalgamation of Iberia to Eurasia at around $30 \mathrm{Ma}$ coincides with the major change in active plate boundary to the left lateral Azores-Gibraltar zone south of Iberia. Whereas Iberia was hindered progressively in its eastward motion by the collision with Eurasia, Africa kept moving eastward, causing an active left lateral motion plate boundary to the south of Iberia and opening of the Valencia Trough and Balearic Basin to the east (Sabat et al., 1995). Extension in this region started as early as Oligocene onshore southern France (related to the Rhine-Bresse Graben system) and shifted progressively southwestward, arriving by Early Miocene (23-20 Ma) in the Alboran domain (Sanz de Galdeano, 1996).

A change in direction of convergence from NNW to NW between Africa and Eurasia in the Tortonian (Mazzoli and Helman, 1994) led to the major structuration of the Betics (Biermann, 1995) and Spanish Central System (De Vicente et al., 1996) and inversion tectonics in the late Tortonian-Messinian in the Alboran Basin (Lonergan and White, 1997). A high level of internal deformation leading to a largescale Pliocene uplift of several hundreds of metres of eastern Iberia (Janssen et al., 1993), and present-day seismicity (Buforn et al., 1988), accompanies the ongoing convergence between Africa and Iberia (Argus et al., 1989).

\section{2. (Palaeo)stress trajectories in Iberia}

The effects of the far-field stresses caused by plate motions are reflected in the (palaeo)stress patterns of the Iberian Peninsula. Regional reconstructions of the stress-trajectories for different time intervals of central Iberia (De Vicente et al., 1996), the Betic and Rif (Galindo-Zaldivar et al., 1993) and offshore Portugal (Ribeiro et al., 1996) using focal mechanism solutions, faults slip data or borehole breakout data, yielded fairly uniform spatial patterns. This is due to the fact that the larger the area considered, the more the local perturbations (second or third order, Zoback, 1992) will smooth out resulting in a pattern of stress trajectories that can be explained largely by the far-field stresses (first order, Zoback, 1992) only. The overall stress field in Iberia can to a first order be explained by the convergence between Eurasia and Iberia for the Palaeogene-Early Miocene, whereas the influence of the convergence between Eurasia/Iberia and Africa is able to explain the Middle Miocene to present-day first-order stress field (Zoback, 1992).

On a smaller, basin-wide scale, local stress fields are documented very well, both in time and place. For the palaeostress determination based on fault slip data, especially for central Spain (e.g. De Vicente et al., 1996), the Betic region (e.g. De Ruig, 1990; Biermann, 1995), the Iberian Chain (e.g. SimonGomez, 1986), Ebro Basin (e.g. Guimera, 1984) and southeastern foreland of the Pyrenees (e.g. Guimera, 1984), a considerable amount of data has been gathered and published. The Tertiary basins in Iberia form good sites for palaeostress studies, since their sedimentary infill is significant, episodic and relatively young. The latter implies that the sediments witnessed only the last deformational stages which makes it easier to distinguish different deformation stages. Moreover, very often, the sediments are deformed moderately, forming abundant deformational structures without large-scale rotations, satisfying some of the basic assumptions of the palaeostress method. The internal structure of the sedimentary infill imaged by reflection seismics (e.g. Querol, 1989; Pulgar et al., 1995; Sabat et al., 1995) contains a large body of information on the tectonic activity of the areas bordering the basins.

A deformational stage can in many cases be attributed relatively well to a specific sedimentary interval by the spatial restriction of structures related to this deformation (e.g. De Vicente et al., 1996; Huibregtse et al., 1998). However, absolute dating of that specific sedimentary interval is in many regions very difficult because of the lack of good biostratigraphic markers in most of the continental sediments and in that way hinders precise dating of the deduced tensors and changes in their orientation. For the numerous smaller basins of the Betic region, marine environments prevailed throughout a large part of the Miocene, and as a result the time constraints are well defined in this region. For the larger internal basins such as the Madrid, Ebro and 


\section{Focal depth $(\mathrm{km})$}
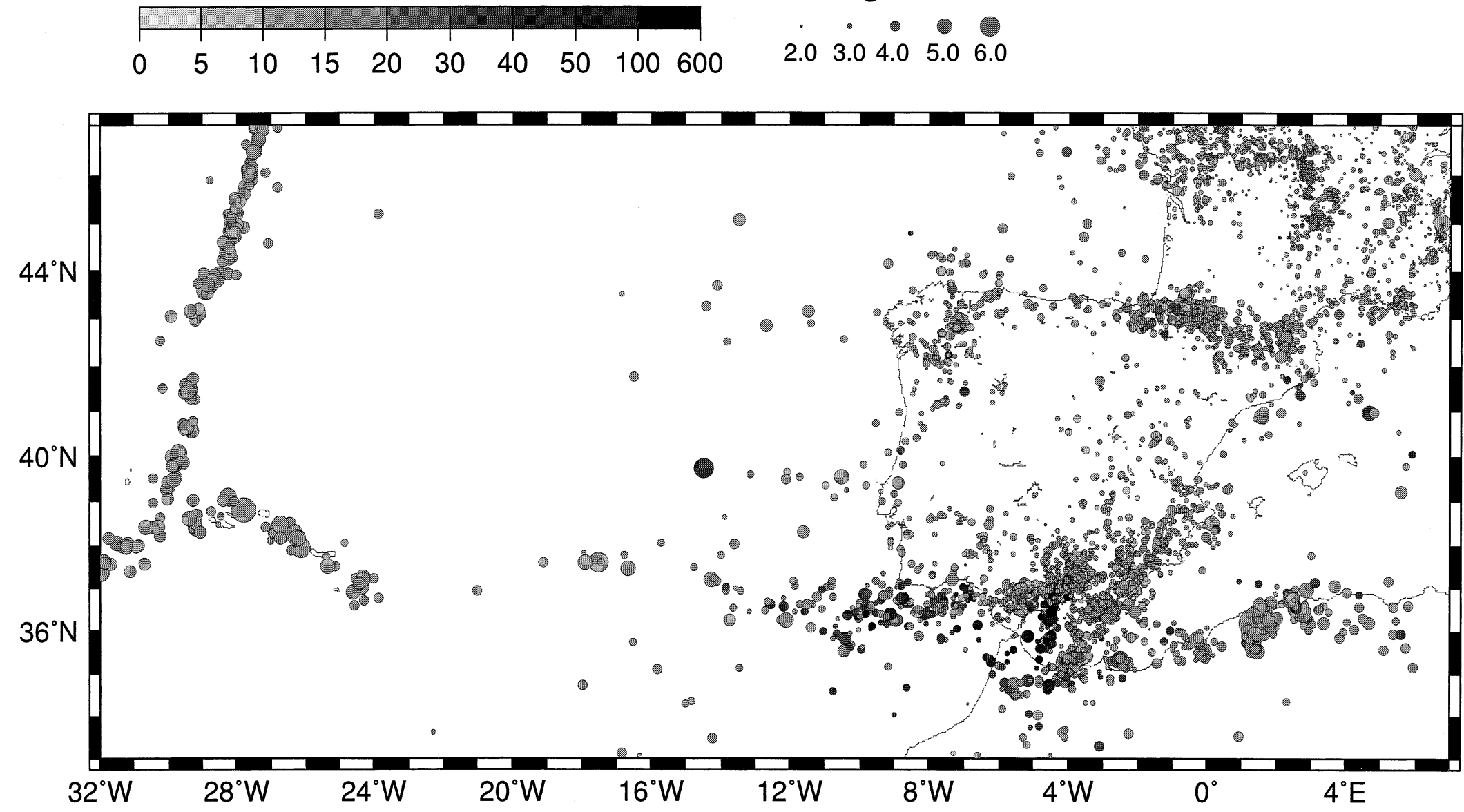

Fig. 2. Seismicity distribution of Iberia and surrounding areas from 1980 to 1998 , showing location, magnitude $\left(M_{\mathrm{b}}\right)$ and focal depth. Mayor part of the seismic activity is related clearly to the presently active (spreading of the Azores Ridge and Terceira Ridge and convergence along the southern plate boundary) and former plate boundaries (Betic region, Pyrenees) that obviously still form zones of weakness. Intraplate seismicity is restricted to the northern and eastern coast segments (note alignment of events) and the central parts of Iberia. Compilation of on-line available data of Instituto Geografico Nacional of Spain (IGN) and Northern California Earthquake Data Center (NCEDC)/Council of the National Seismic System (CNSS). 
Duero basins, correlation of dated lacustrine deposits in the central parts to the marginal continental type of sediments is most often the best approach (Calvo et al., 1993). With respect to the numerous smaller, intramountainous basins (e.g. Bierzo Basin, Fig. 1) the absolute dating of the Tertiary sediments is poor; as a best approximation the sediments are correlated on base of their nature (fluvial; distal or proximal) and lithology (red conglomerates, silts, sands and clays) with sediments of better constrained age in the larger basins (e.g. Martin-Serrano et al., 1996).

Even for cases where accurate dating of sediments and thus stress field changes has been possible (e.g. Huibregtse et al., 1998), correlation of deduced stress tensors over larger distances has not always been very straightforward. The scale of the studies shows that important local or regional deviations of the stress field occurred for most of the Tertiarypresent: the stress field in Iberia has been far from homogeneous.

With respect to the present-day stress field, data on borehole breakouts (e.g. Ribeiro et al., 1996; Jurado and Mueller, 1997) and focal mechanisms (e.g. Buforn et al., 1988; De Vicente et al., 1996) are becoming rapidly available and are being incorporated in the World Stress Map database. Distribution of seismicity in the Iberian region from 1980 (the year for which the Iberian seismic network improved significantly) to present shows clearly (see Fig. 2) the active and formerly active plate boundaries of Iberia. The spreading Azores and Terceira ridges (the latter induced by the anti-clockwise rotation of Africa with respect to Eurasia around a pole located at around $20^{\circ} \mathrm{N} / 20^{\circ} \mathrm{W}$, Argus et al., 1989) show surficial $(<10 \mathrm{~km})$ seismic activity, restricted to the thin oceanic crust. The more diffuse southern active plate boundary seems to be reflected by the alignment of deeper-seated earthquakes (30-150 km, standard error for depth less than $15 \mathrm{~km}$ ) in lower crustal and mantle levels in northern Africa to events along the Gloria Fault. Two deep events (up to $650 \mathrm{~km}$, Buforn et al., 1988) have been attributed to a detached lithospheric slab (Blanco and Spakman, 1993), the remnant of subduction (Lonergan and White, 1997) or delaminated lithosphere (Seber et al., 1996). Formerly active plate boundaries still show alignment and clustering of seismicity due to their inherited weakness, as for example, the Pyrenees and the di- vision line between the Betic realm and the part of Iberia that has been stable since the Mesozoic (Vegas et al., 1990).

Seismicity in the interior of Iberia shows large aseismic zones in central western Iberia and the Duero Basin. In the latter case, this can be related to a basement that is likely very stable as reflected by the relatively rigid response to loading of its northern border by the southward thrust Cantabrian Cordillera (Pulgar et al., 1995). Furthermore, a remarkable occurrence of earthquakes along the northern and western coast can be observed.

The available focal mechanism solutions of these seismic events, borehole breakout data and Quaternary fault slip data (De Vicente et al., 1996) have been used to create trajectory maps of the presentday stress field (see Fig. 3).

\section{Local deformation in central Iberia}

Documented inhomogeneities of the stress field can be used to estimate the relative role of the various far-field stresses and stresses induced by local deformation (e.g. bending stresses) or lateral density variations (buoyancy forces induced by topography or crustal structure) for the tectonically active interval for the given examples. We present three examples and discuss the constraints they yield on the activity of the plate boundaries of Iberia.

\subsection{Sierra de Altomira}

This N-S-trending fold-and-thrust belt in central Spain (see Figs. 1 and 4) is a somewhat enigmatic feature. In an overall $\mathrm{N}-\mathrm{S}$ compressional setting, it extruded to the west. Nucleation of faulting and folding has been related to the western culmination of the plastic facies of the Upper Triassic (Keuper) under the Mesozoic cover (Van Wees et al., 1995) to the presence of a basement fault that was active as a normal fault during the Mesozoic. In the later compressional stage both features (a basement step and culmination of the decoupling layer) generated stress concentration at the tip of the fault (Muñoz Martin et al., 1998) and possible decoupling restricted to the downthrown block only. The active period of this structure is defined by the sediments deformed in the structure and 


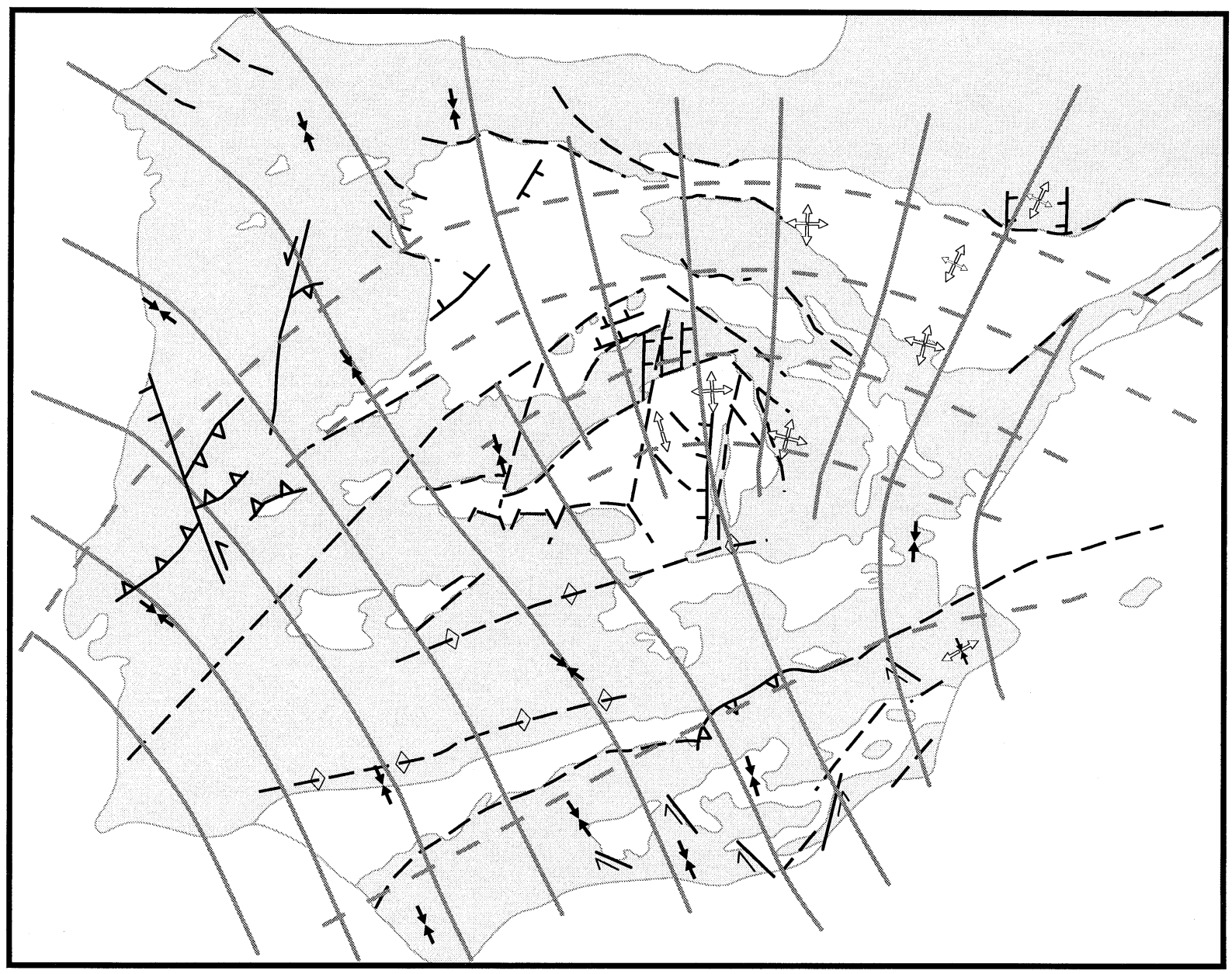

Fig. 3. Compilation of stress state data for Quaternary to the present day from fault-slip data, focal mechanism solutions, bore-hole breakout analysis and active faults (e.g. Ribeiro et al., 1996; De Vicente et al., 1996; own unpublished data; Jurado and Mueller, 1997; Buforn et al., 1988). Thick solid grey lines denote reconstructed $S_{\mathrm{hmax}}$ direction, thick dashed lines denote $S_{\mathrm{hmin}}$ trajectories.

a well defined upper limit formed by Upper Miocene sediments that onlap the Altomira structures (Gomez et al., 1996). The onset of deformation thus took place under the approximately NNE compression related to the Pyrenean collision of Iberia with Eurasia; the upper limit of its activity lies within the timespan (Middle Miocene) for which the approximately NNW Betic compression became the dominant stress field. The extrusion to the west of the Sierra de Altomira therefore, seems to be the result of a local stress field (the 'Altomira' stress field, Muñoz Martin et al., 1998) that was active in this region in between the much more regional Pyrenean and Betic stress fields. The local geological setting (the presence of the basement fault, the decollement level) and its position in the interior of Iberia, focusing the effects from the different plate boundaries, have enhanced this deformation. Finite-element studies have predicted the N100E compression required for the observed deformation in the Sierra de Altomira region by adding the remnant of the Pyrenean compression from the north and the onset of Betic compression from the south (Muñoz Martin et al., 1998).

If this hypothesis is accepted, it bears several implications for the activity of the boundaries of the microplate Iberia and the resulting state of stress of its interior. This explanation of the development of the Altomira structure points to a gradual change in 


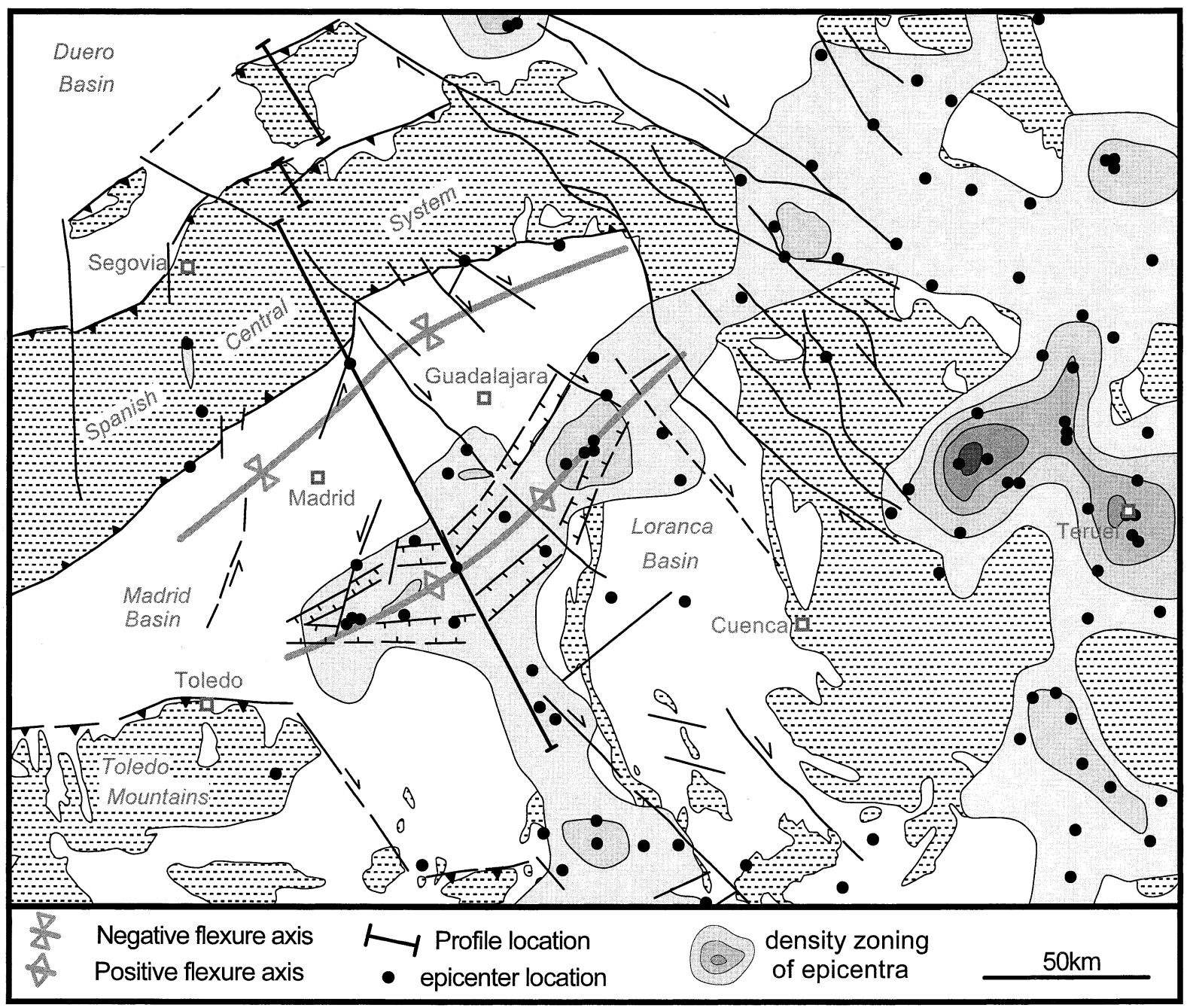

Fig. 4. Recent and present-day deformation in the Madrid Basin and surroundings, showing seismicity distribution (dots) and major Tertiary to present active faults (De Vicente et al., 1996). Dashed area denotes basement older than Tertiary, the white area marks the Tertiary and younger basins. Note normal faulting along the major valleys in the central part of the Madrid Basin and concentration of seismicity in the same region. See for location box in Fig. 1.

the active plate boundaries through time for Iberia, during which superposition of the Pyrenean, Atlantic and Betic stress fields induced a local ('Altomira') stress field. Due to the rapid alternation of activity along its plate boundaries, the stress field in Iberia has been far from homogeneous from the Early Tertiary onwards. Superposition of several of the farfield stresses produced at the different boundaries of Iberia were transmitted to the interior and must have caused during the whole timespan regions with different stress states and maximum compression $\left(S_{\text {hmax }}\right)$ directions changing within several hundreds of kilometres. Correlation of contemporaneous deformation related to these local stress fields over larger areas therefore, might not be straightforward.

\subsection{Madrid Basin}

Numerous palaeostress tensors deduced from fault-analyses in Middle Miocene-Quaternary sed- 
iments within the Madrid Basin (MB) and focal mechanism solutions indicate the presence of two contemporaneous stress fields active from Middle Miocene to present: NNW-SSE compression and subparallel NNW-SSE extension (De Vicente et al., 1996). We will first discuss briefly the origin of the $\mathrm{MB}$, since this influenced the more recent tectonic activity of the basin and its borders.

The intraplate Cenozoic Madrid Basin is part of the Tajo Basin, located in the central part of Spain (see Figs. 1 and 4). Its northern border is formed by the Spanish Central System (SCS), an intraplate mountain range with presently an elevation up to $2600 \mathrm{~m}$, standing up to $2000 \mathrm{~m}$ above the basins on both sides. The development of this intraplate mountain range is due to multiple reactivation of late Hercynian basement faults. During the Palaeogene the WSW-ENE-trending boundary faults of the SCS favoured sinistral strike-slip movement under the NNE-SSW compression of the Pyrenees (Vegas et al., 1990). In the northeastern part of the SCS this led to a transpressive setting causing flower-type structures, which can be documented in the thin Mesozoic cover and early Palaeogene sediments. Under this compressional stress regime the eastern border (the Iberian Chain, IC) thrust onto the Madrid Basin basement. Deformation continued under an approximately E-W compression which resulted from the superposition in place and time of the Pyrenean and Betic compression, forming the abovementioned Sierra de Altomira. Upon waning of the Pyrenean compression, the situation reversed: the IC became a major dextral strike-slip zone (lateral offset estimated up to $35 \mathrm{~km}$ ), whereas the boundary faults of the SCS were oriented in favour of thrust-faulting under the Betic NNW-SSE compressional stress field. The flower-type inheritance of the SCS favoured the popping up of the mountain belt during Middle Miocene. The northern boundary of the SCS was formed by a gently southward-dipping fault aligned to existing weakness planes formed by schistosity, creating a piggyback type of setting. The Southern Boundary Fault (SBF) was oriented much steeper creating a different, more active type of basin setting: the uplift, loading by southward thrusting of the SCS and sedimentation created a deep foreland basin containing 2000-3500 m of sediments of predominantly late Palaeogene-Late Miocene age
(Querol, 1989). The active southward thrusting of the SCS seems to have ended at around the Pliocene. Vast sheets of conglomerates cover the proposed SBF in the northeast of the SCS.

Palaeostress studies (De Vicente et al., 1996) show an abundance of deformational structures of Middle Miocene to Quaternary sediments in the central part of the MB on different scales. The major valleys in this region show obvious straight traces (see Fig. 4), bounded by normal faults creating hanging valleys on either side. Deformation of Quaternary sediments is restricted to the same zone as the seismically active area.

Presently the major thrust front of the SBF is bisected by smaller strike-slip faults trending NNE (sinistral) or NW (dextral). Part of the seismic activity along the southern border of the SCS seems restricted to these strike-slip faults (see Fig. 4). Distribution of seismicity in the $\mathrm{MB}$ is restricted to a very well defined zone, trending approximately parallel to the SCS, some $50-70 \mathrm{~km}$ to the south of the major thrust front, coinciding with the flexural bulge of the SCS-MB Miocene foreland system. A large part of the focal mechanism solutions are compatible with an overall NNW-SSE compression due to the ongoing convergence between Africa and Iberia, whereas some indicate extension exactly parallel to this overall compressional direction (De Vicente et al., 1996). These findings are compatible with flexural upbending of the lithosphere causing extensional bending stresses at shallow levels, whereas at depth compression will prevail below a neutral surface. Although more data on focal mechanisms are required to support this hypothesis, projection of the known focal mechanisms onto a cross-section seems to indicate a spatial separation between the extensional and compressional earthquakes (see Fig. 5). The neutral surface in this case is due to scarceness of data, lateral projection and errors in focal depth determination not well defined yet, but Fig. 5 shows that the shallowness of several compressional events points to a neutral surface around 5-7 km. This seems to be in the same order as the EET (effective elastic thickness) value of $7 \mathrm{~km}$ obtained by flexural basin modelling (Van Wees et al., 1995). This value, however, might be an underestimation, since the spatial distribution of present-day seismicity and Quaternary deformation indicates a present amplification 


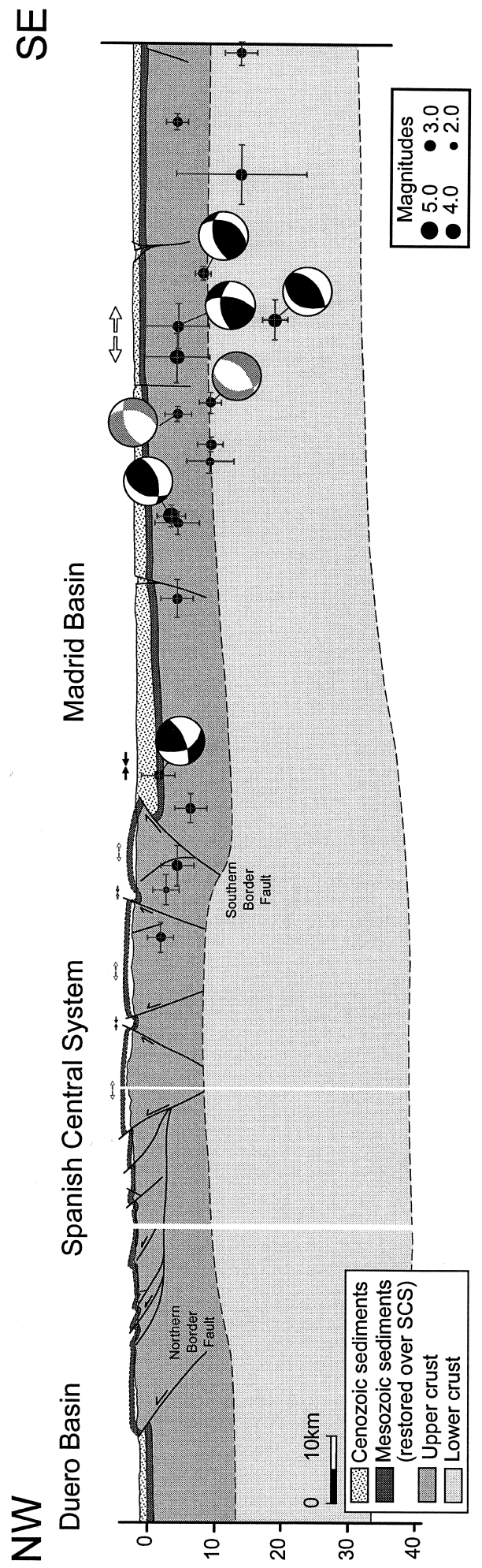

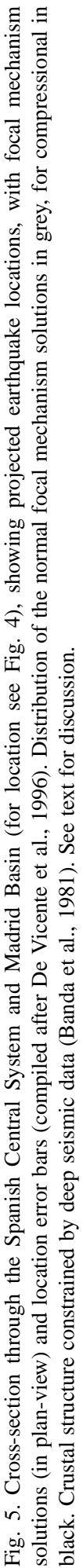

of the initial foreland-bulge of the MB-SCS due to intraplate compression. Therefore, the present-day curvature of the plate should not be considered as the result of flexural loading by the SCS only.

The MB compression-parallel extension can in this way be explained as a surficial expression of the overall NNW-SSE compressional regime active in central Iberia from about Middle Miocene to the present day and should therefore not be regarded as a distinct extensional phase within the tectonic framework. Rather than attributed to a regional extensional setting, this extension should be regarded as the effect of flexural bending stresses resulting out of a regional compression.

\subsection{Pronounced seismic activity in Galicia}

A remarkable concentration of earthquakes along the northern and western coasts of Iberia can be observed (see Fig. 2). Focal mechanism solutions of the pronounced Lugo seismic activity in Galicia, NW Iberia (November 1996-May 1997 in approx. $20 \mathrm{~km}^{3}>250$ events ranging in considerable magnitudes from 3.0 to $5.1\left(M_{\mathrm{b}}\right)$ for the large distance from the active plate boundaries) indicate movement of normal faults trending roughly $\mathrm{N}-\mathrm{S}$, which would not be consistent with the expected more or less NW-SE compressional regime in this area. More focal mechanism solution data are required, but it seems no coincidence that this concentration of seismicity occurred at the spur of the seismic alignments of the northern and western coasts. When convergence between Africa and Eurasia started, Iberia became squeezed between both plates. Escape to the west has been impeded by the opening Atlantic leading to internal deformation as the prime mode to accommodate the induced strain. The Iberian Peninsula shows significant internal deformation, has a thickened crust, average at about $30-35 \mathrm{~km}$ and relatively elevated average topography. Coblentz et al. (1994) tested the effect of crustal inhomogeneities on the local stress state by calculating potential energy and found that extensional stresses are generated parallel to the trend of the change in crustal inhomogeneities. Finite-element models on the stress field for the shelf of mid-Norway (Gölke et al., 1996) where the margin is perpendicular to the far-field compression, show second-order tensile stresses that 
are large enough to create a local stress state with a small stress anisotropy (the horizontal principal stresses are about the same in magnitude, which enables permutation of the maximum and intermediate principal axes). The large step in both topography and thickness of the crust along the western and northern coasts (see Fig. 1) of Iberia cause potential energy-driven tensional stresses in the same order of magnitude (about $15 \mathrm{MPa}$, Gölke and Coblentz, 1996). Results of Gölke and Coblentz (1996) show that if stresses generated by distributed ridge push and buoyancy forces are incorporated, the direction of $S_{\text {hmax }}$ does not change significantly for continental Iberia (see Fig. 6, all panels). The local state of stress
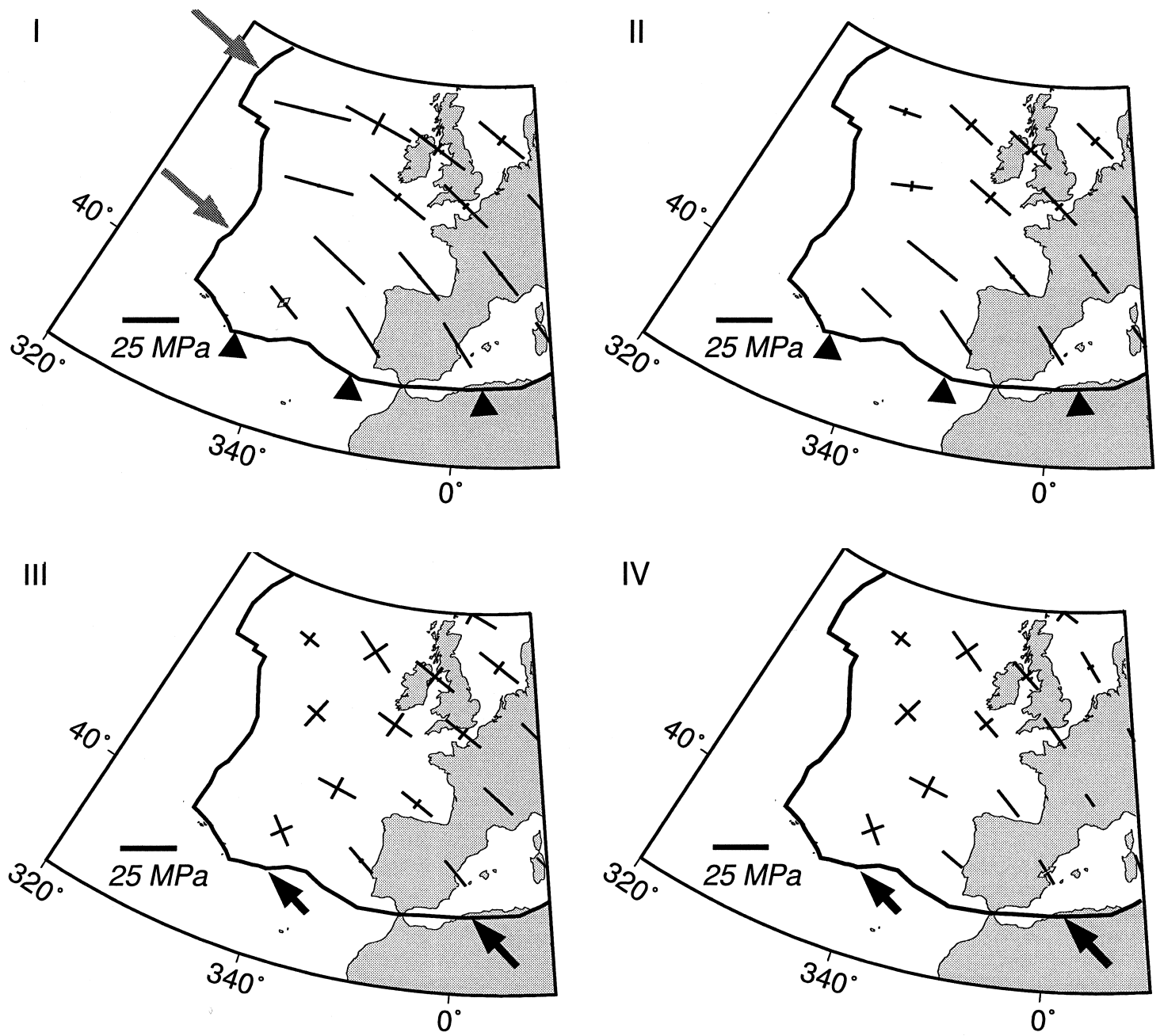

Fig. 6. Prediction from numerical modelling of the stress field of western Europe (after Gölke and Coblentz, 1996); model results for a reference thickness of $100 \mathrm{~km}$ using a uniform elastic rheology. Panels display the predicted stress patterns in Iberia and surrounding areas for different models, involving different assumptions on boundary conditions and distribution of plate driving forces. Panel I: $S_{\mathrm{hmax}}$ direction if ridge push is represented as a line force acting on the spreading edge, fixed southern boundary. Panel II: ridge push represented as distributed forces, fixed southern boundary. Panel III: ridge push as distributed forces, collisional forces applied to southern boundary. Panel IV: as in panel III with incorporation of distributed forces induced by topography. Note that $S_{\mathrm{hmax}}$ direction does not change for continental Iberia, whereas magnitude and the local stress state and therefore the resulting deformational style do change significantly. 
in Iberia, however, is altered very much as well by reduction of the $S_{\mathrm{hmax}}$ magnitude (see Fig. 6, panel I versus panel IV) as by increasing importance of the other principal stresses (unaxial compression versus strike-slip regime). For the oceanic part, it is clear that incorporation of these forces (compare panel II with panels III and IV in Fig. 6) leads to a dramatic change in stress field orientation and magnitude. The orientation of the present-day compressional stress is at large angles to both the northern and the western coast of Iberia, in other words, subparallel to the tensile stresses induced by the lateral density variations along these margins. The latter will, in this case, counteract at least part of the general compressional stress state. The extent to which the local stress state is influenced by the forces due to potential energy differences, can therefore reveal information about the magnitude and orientation of the far-field stresses and thus, indirectly about activity of the different plate boundary forces. For more precise linking of local states of stress or deformation and absolute magnitudes of plate boundary forces, more detailed knowledge on the crustal structure, the rheology and its variations is required.

Since the seismicity of this region has to be explained within the present-day, roughly NNW-SSE compressional stress field for Iberia, the local stress state inferred from focal mechanism solutions along the northern and western borders of the continent provides constraints on magnitude of the collisional forces exerted by Africa along the southern plate boundary and the strength of the lithosphere in this part of Iberia.

\section{Conclusions}

In a setting of quite rapid alternation of several far-field stress sources, as in the case of Iberia for the timespan of early Tertiary onwards, local stress states can be the effect of a spatial and temporal superposition of some of these far-field stress forces. This can create regions with significantly different local stress states within small distances. Therefore, spatial and temporal correlation of observations on local deformation might not always be very straightforward and should be imbedded in the tectonic framework of such an area.
If, however, local deformation in the interior of a continent can be explained satisfactorily within its tectonic framework, data on the spatial and temporal changes of the local stress state can provide a significant and quantitative source of information about the activity of the plate boundaries.

\section{Acknowledgements}

We would like to thank Ramon Vegas for useful discussions on (neo)tectonic models for Iberia, and Marlies ter Voorde for improvements on early drafts. B.A. acknowledges the Netherlands Organisation of Scientific Research (NWO/GOA) for financially supporting this study (proj. number 750.295.02A) and the presentation at the Penrose Conference on 'Tectonics of Continental Interiors'. Contribution Nr. 980601 of the Netherlands Research School of Sedimentary Geology.

\section{References}

Argus, D.F., Gordon, R.G., DeMets, C., Stein, S., 1989. Closure of the Africa-Eurasia-North America plate motion circuit and tectonics of the Gloria Fault. J. Geophys. Res. 94, 5585-5602.

Banda, E., Suriñach, E., Aparicio, A., Sierra, J., Ruiz de la Parte, F., 1981. Crust and upper mantle structure of the central Iberian Meseta (Spain). Geophys. J.R. Astron. Soc. 67, 779789.

Biermann, C., 1995. The Betic Cordilleras (SE Spain). Anatomy of a dualistic collision type orogenic belt. Geol. Mijnbouw 41, 167-182.

Blanco, M.J., Spakman, W., 1993. The P-wave velocity structure of the mantle below the Iberian Peninsula: evidence for subducted lithosphere below southern Spain. Tectonophysics 221, $13-34$

Boillot, G., Malod, J., 1988. The north and north-west Spanish continental margin: a review. Rev. Soc. Geol. Esp. 1, 295-316.

Buforn, E., Udias, A., Colombas, M.A., 1988. Seismicity, source mechanisms and tectonics of the Azores-Gibraltar plate boundary. Tectonophysics 152, 89-118.

Calvo, J.P., Daams, R., Morales, J., Lopez-Martinez, N., Agusti, J., Anadon, P., Armenteros, I., Cabrera, L., Civis, J., Corrochano, A., Diaz-Molina, M., Elizaga, E., Hoyos, M., Martin-Suarez, E., Martinez, J., Moissenet, E., Muñoz, A., PerezGarcia, A., Perez-Gonzalez, A., Portero, J.M., Robles, F., Santisteban, C., Torres, T., Van der Meulen, A.J., Vera, J.A., Mein, P., 1993. Up-to-date Spanish continental Neogene synthesis and paleoclimatic interpretation. Rev. Soc. Geol. Esp. 6, 29-40.

Coblentz, D.D., Richardson, R.M., Sandiford, M., 1994. On the 
gravitational potential of the Earth's lithosphere. Tectonics 13, 929-945.

De Jong, K., 1990. Alpine tectonics and rotation pole evolution of Iberia. Tectonophysics 184, 279-296.

De Ruig, M.J., 1990. Fold trends and stress deviation in the Alicante fold belt, southeastern Spain. Tectonophysics 184, 393-403.

De Vicente, G., Giner, J.L., Muñoz Martin, A., Gonzalez-Casado, J.M., Lindo, R., 1996. Determination of present-day stress tensor and neotectonic interval in the Spanish Central System and Madrid Basin, central Spain. Tectonophysics 266, 405424.

Galindo-Zaldivar, J., Gonzalez-Lodeiro, F., Jabaloy, A., 1993. Stress and paleostress in the Betic-Rif cordilleras (Miocene to the present). Tectonophysics 227, 105-126.

Garcia-Mondejar, J., 1996. Plate reconstruction of the Bay of Biscay. Geology 24, 635-638.

Gölke, M., Coblentz, D., 1996. Origins of the European regional stress field. Tectonophysics 266, 11-24.

Gölke, M., Cloetingh, S., Coblentz, D., 1996. Finite element modelling of stress patterns along the Mid-Norwegian continental margin, $62^{\circ}$ to $68^{\circ} \mathrm{N}$. Tectonophysics $266,33-53$.

Gomez, J.J., Diaz-Molina, M., Lendinez, A., 1996. Tectono-sedimentary analysis of the Loranca Basin (upper OligoceneMiocene, Central Spain): a 'non-sequenced' foreland basin. In: Friend, P.F., Dabrio, C.J. (Eds.), Tertiary Basins of Spain, the Stratigraphic Record of Crustal Kinematics. World and Regional Geology 6, Cambridge University Press, Cambridge, pp. 285-294.

Guimera, J., 1984. Paleogene evolution of deformation in the north-eastern Iberian Peninsula. Geol. Mag. 121, 413-420.

Huibregtse, P.W., van Alebeek, J.M., Zaal, M.E.A., Biermann, C., 1998. Paleostress analysis of the northern Nijar and southern Vera Basins: constraints for the Neogene displacement history of major strike-slip faults in the Betic Cordilleras, SE Spain. Tectonophysics 300, 79-101.

Janssen, M.E., Torne, M., Cloetingh, S., Banda, E., 1993. Pliocene uplift of the eastern Iberian margin: Inferences from quantitative modelling of the Valencia Trough. Earth Planet. Sci. Lett. 119, 585-597.

Jurado, M.J., Mueller, B., 1997. Contemporary tectonic stress in NE Iberia. New evidence from borehole breakout analysis. Tectonophysics 282, 99-115.

Lonergan, L., White, N., 1997. Origin of the Betic-Rif mountain belt. Tectonics 16, 504-522.

Martin-Serrano, A., Mediavilla, R., Santisteban, J.I., 1996. North-western Cainozoic record; present knowledge and correlation problem. In: Friend, P.F., Dabrio, C.J. (Eds.), Tertiary Basins of Spain, the Stratigraphic Record of Crustal Kinematics. World and Regional Geology 6, Cambridge University Press, Cambridge, pp. 237-246.

Mazzoli, S., Helman, M., 1994. Neogene patterns of relative plate motion for Africa-Europe: some implications for recent central Mediterranean tectonics. Geol. Rundsch. 83, 464-468.

Muñoz Martin, A., Cloetingh, S., De Vicente, G., Andeweg, B., 1998. Finite-element modelling of Tertiary paleostress fields in the eastern part of the Tajo Basin (Central Spain). Tectonophysics 300, 47-62.

Puigdefabregas, C., Souquet, P., 1986. Tecto-sedimentary cycles and depositional sequences of the Mesozoic and Tertiary from the Pyrenees. Tectonophysics 129, 173-203.

Pulgar, J.A., Perez-Estaun, A., Gallart, J., Alvarez-Marron, J., Gallastegui, J., Alonso, J.L., ESCIN Group, 1995. The ESCI-N2 deep seismic reflection profile: a traverse across the Cantabrian Mountains and adjacent Duero Basin. Rev. Soc. Geol. Esp. 8, 383-394

Querol, R., 1989. Geologia del subsuelo de la Cuenca del Tajo. ITGE-ETSIM, Madrid, 48 pp.

Ribeiro, A., Baptista, R., Cabral, J., Matias, L., 1996. Tectonic stress patterns in Portugal Mainland and the adjacent Atlantic region (west Iberia). Tectonics 15, 641-659.

Sabat, F., Roca, E., Muñoz, J.A., Verges, J., Santanach, P., Sans, M., Masana, E., Estevez, A., Santisteban, C., 1995. Role of extension and compression in the evolution of the eastern margin of Iberia: the ESCI-Valencia Trough seismic profile. Rev. Soc. Geol. Esp. 8, 431-448.

Sanz de Galdeano, C.M., 1996. Tertiary tectonic framework of the Iberian Peninsula. In: Friend, P.F., Dabrio, C.J. (Eds.), Tertiary Basins of Spain, the Stratigraphic Record of Crustal Kinematics. World and Regional Geology 6, Cambridge University Press, Cambridge, pp. 9-14.

Savostin, L.A., Sibuet, J., Zonenshain, P., Le Pichon, X., Roulet, M., 1986. Kinematic evolution of the Tethys belt from the Atlantic Ocean to the Pamirs since Triassic. Tectonophysics 123, 1-35.

Seber, D., Barazangi, M., Ibenbrahim, A., Demnati, A., 1996. Geophysical evidence for lithospheric delamination beneath the Alboran Sea and Rif-Betic mountains. Nature 379, 785790 .

Simon-Gomez, J.L., 1986. Analysis of a gradual change in stress regime (example of the eastern Iberian Chain, Spain). Tectonophysics $124,37-53$.

Srivastava, S.P., Roest, W.R., Kovacs, L.C., Oakley, G., Levesque, S., Verhoef, J., Macnab, R., 1990. Motion of Iberia since the Late Jurassic: results from detailed aeromagnetic measurements in the Newfoundland Basin. Tectonophysics 184, 229-260.

Van Wees, J.D., Cloetingh, S., De Vicente, G., 1995. The role of pre-existing weak zones in basin evolution: constraints from 2D finite element and 3D flexure modelling. In: Buchanan, P.G., Nieuwland, D.A. (Eds.), Modern Developments in Structural Interpretation, Validation and Modelling. Geol. Soc. London Spec. Publ. 99, 297-320.

Vegas, R., Vazquez, J.T., Suriñach, E., Marcos, A., 1990. Model of distributed deformation, block rotations and crustal thickening for the formation of the Spanish Central System. Tectonophysics $184,367-378$.

Ziegler, P.A., 1988. Evolution of the Arctic-North Atlantic and the western Tethys. Am. Assoc. Pet. Geol. Mem. 43, 198 pp.

Zoback, M.L., 1992. First- and second-order patterns of stress in the lithosphere: The World Stress Map Project. J. Geophys. Res. 97, 11703-11728. 